\section{SLAC accounting for damage?}

\section{Washington}

STANFORD University is once again struggling to clear its name against the accusation that it has defrauded the US federal government. The latest accuser is Tim Axe, a former employee at the Stanford Linear Accelerator Center (SLAC), who alleges that his supervisor, Bill Voreyer, encouraged him to submit a fraudulently inflated estimate to the Department of Energy for the cost of repairing damage at SLAC caused by the Loma Prieta earthquake in October 1989. Axe first contacted Stanford president Donald Kennedy with his allegations last February, but when Stanford completed its own internal audit report on the incident and found no fraud, Axe approached a local California newspaper, the San Jose Mercury News, with his story.

In February 1990, Axe alleges, he was asked to make an estimate of earthquake damages that would support Voreyer's initial assessment of $\$ 480,000$, made in the week following the earthquake. Axe says that instead he calculated the total damage caused by the earthquake to be about $\$ 50,000$. Axe claims that Voreyer SCIENCE MAGAZINES damage estimate. SLAC could spend as it liked. properly. told him, "if you find some work that needs to be done and you can't say it was done by the earthquake, go ahead and charge it to this [the earthquake damage] account". Axe also alleges that he was dismissed because of his refusal to increase his estimate. SLAC director Burton Richter says that Axe's dismissal was entirely unrelated to the earthquake

According to Stanford's internal audit, there are "no grounds for considering a misappropriation of funds", because the Department of Energy never provided SLAC with a specific sum of money earmarked for the earthquake repairs instead, the laboratory received a largerthan-usual operating budget from the energy department for 1990, which

Nevertheless, Stanford officials have not yet dismissed Axe's fundamental complaint that he was asked to 'pad' his estimate to win more funds. Stanford's outside auditing firm, Coopers and Lybrand, has now been asked to examine Axe's claim that his superiors acted im-

Peter Aldhous

\section{Discover suspends activities}

\section{Washington}

Discover, the only popular US science magazine aimed at lay readers, was closed last week. The magazine's demise came as a shock to most of its editorial staff, who learned of the winding up only on 7 August - a day before it was announced publicly. Although Discover itself has shown a profit, its parent company, Family Media of New York, decided to shut down because of falling

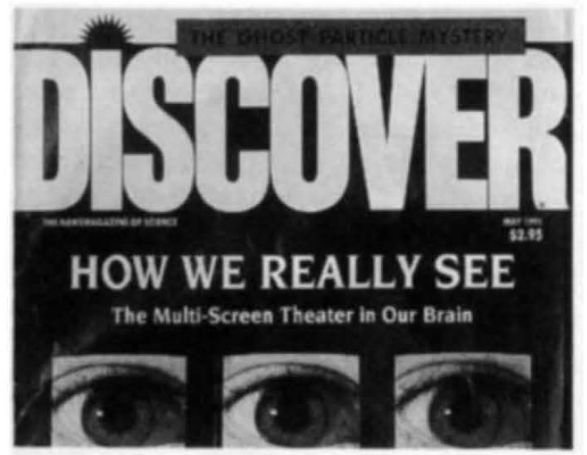

advertising revenues. "Discover just wasn't enough to carry everyone else along," says Marc Zabludoff, the magazine's executive editor.

Discover's staff are optimistic that a buyer can be found to relaunch the title. The American Association for the Advancement of Science (AAAS) has been mentioned as a possible buyer by some of the magazine's contributing editors, but NATURE - VOL $352 \cdot 15$ AUGUST 1991

\section{Grand Canyon, clearly}

\section{Washington}

BY the end of the decade, visitors to the Grand Canyon may get a better view of its spectacular scenery, thanks to a newfound spirit of cooperation between the owners of an Arizona electricity generating plant and their erstwhile environmentalist critics.

The Salt River Project, representing the six co-owners of the Navajo coal-fired station (which include the US Interior Department), last week agreed to submit to the Environmental Protection Agency (EPA) a proposal that would cut the plant's sulphur dioxide emissions by 90 per cent by 1999. The proposal was drafted by the Grand Canyon Trust, an environmentalist group that, together with the US National Park Service, has long argued that the Navajo plant contributes significantly to the haze that can obscure views of the Grand Canyon. The Navajo plant's owners have disputed this claim, and had baulked at an earlier EPA proposal to cut the station's sulphur dioxide emissions by only 70 per cent.

The apparent change of heart is due to simple economics. Under the Clean Air Act, EPA was going to force emissions cuts on the plant whether its owners objected or not, and the agency's proposal had been estimated to cost around $\$ 3,000$ million, spread over 20 years. The new plan would cost only $\$ 1,800$ million over the same period, according to the Salt River Project. Despite greater emissions cuts, it is cheaper because it allows the Navajo plant's operators to measure the cuts on the basis of a yearly average of emissions, rather than the 30 -day average proposed by EPA.

Peter Aldhous

\section{BRITISH SCIENCE}

WE shall be publishing on 12 September Nature's Manifesto for British Science, which will be offered without charge to any one of the political parties contesting the next general election and in the belief that it is an improvement on their own version.

Following publication, on Friday 13 September, there will be a public meeting at the Royal Institution, Albemarle Street, London W1, at which Sir Mark Richmond, chairman of the Science and Engineering Research Council, will be the principal speaker. The chairman will be John Maddox, editor of Nature. The meeting will start at $9.45 \mathrm{a} . \mathrm{m}$. and end at 12.45 p.m. The political parties will be invited to send representatives. but there will be ample time for discussion.

Those wishing to attend should apply for tickets to Mary Sheehan. Nature, 4 Little Essex Street, London WC2R 3LF. at the general US public to make a profit. Any takers?
Peter Aldhous 